\title{
Ironická distance jako forma sociologického náhledu. K 50. výročí vydání The Social Construction of Reality a za Thomasem Luckmannem
}

\author{
Ironical Distance as a Form of Sociological View. On the \\ $50^{\text {th }}$ Anniversary of the Edition of The Social Construction of Reality \\ and after Thomas Luckmann \\ llja Šrubař
}

Bergerova a Luckmannova The Social Construction of Reality je přes všechnu svou čtivost nesnadný text. Je to dáno nejen ambivalencí procesu sociálního konstruování, která vždy znovu textem prosvítá, ale i ironickou distancí, se kterou autoři svou koncepci podávají. Ironická distance je zde důležitým elementem, který čtenáře nutí, aby si uvědomil, jak vlastně sociální konstrukce skutečnosti funguje. Již v úvodu nám autoři sdělují, že svůj vysoce teoretický spis chtěli vlastně věnovat jistému jodlerovi ve Vorarlbergu, ale že se poddávají tlaku všeobecného očekávání a věnují svou knihu neméně zaslouženě svým manželkám. I dále v textu narážíme vždy znovu na pasáže, kde autoři ožrejmují pochody sociálního konstruování úvahami o tom, jak by vypadala armáda, ve které by byla homosexualita všeobecně platnou normou, nebo jak by vznikala mytologie (tj. symbolické univerzum) skupiny skládající se z heterosexuálního páru a lesbické dámy. Těmito ironicky zcizujícími efekty Berger s Luckmannem vyvádějí čtenáře z rámce každodenní samožrejmosti a obracejí jeho pozornost $\mathrm{k}$ mechanismům, kterými tato samozřejmost vlastně vzniká. Dalo by se říci, že zde máme co dělat s literární formou Garfinkelových „breaching experiments“, které vyvolávaly podobné efekty systematickým porušováním pravidel normální každodenní interakce. Jde zde tedy o zvláštní formu praktikované fenomenologické „epoché“, ve které je danost skutečnosti vložena do závorek, aby bylo možno sledovat její konstrukci. To, co se v této ironické epoché sociologovi zjevuje, je znepokojivá ambivalence takto vznikajících konstrukcí, které jsou zároveň jak subjektivním prožíváním, tak i objektivní sociální realitou. Analýza propojení těchto dvou momentů, antropologicky charakterizujících lidskou skutečnost, je vlastním úmyslem Bergerova a Luckmannova textu.

Ironický záměr textu mne oslovil, už když jsem Social Construction jako student četl poprvé. Bylo to počátkem 70. let minulého století ve Frankfurtu nad Mohanem, v době, kdy studentská revolta, započatá $\mathrm{v}$ roce 1968, otřásala městem a univerzitou. Byl letní den, měl jsem trochu času mezi dvěma semináři, ležel jsem na louce v „Palmengarten“ a všude kolem

Sociální studia / Social Studies 3/2016. S. 61-71. ISSN 1214-813X. 
mne si spolustudující obojího pohlaví užívali podobně jako já slunné odpoledne - revoluce sem, revoluce tam. Zahloubán do textu jsem si v této situaci pozvolna uvědomoval, co vlastně Berger a Luckmann sociální konstrukcí reality a zvláště svou koncepcí symbolických univerz smyslu chtějí říci. Zde, na louce v „Palmengarten“, se takových univerz prolínalo hned několik, jak by se jistě ukázalo, kdyby př́tomní kolegové a kolegyně opustili svět momentálně př́jemné studentské každodennosti, vstoupili do teoretických světů svých společenských utopií a dali se do patřičných debat. Rozevřelo by se zde široké spektrum ortodoxních, maoistických a neomarxistických koncepcí, které, k mému skeptickému údivu, hodlaly dát společnosti více či méně autoritární charakter, který pro mne byl právě důvodem toho, že neležím v Praze ve Stromovce, ale ve frankfurtském Palmengartenu. A že takové utopie a jejich prosazování nejsou pouze otázkou napínavých teoretických debat a argumentů, ale že vítězství jedné nad druhou znamená násilné přeskupení celých společnosti mocí, o tom poskytovaly empirickou evidenci tanky v pražských ulicích roku 1968 a následná „,normalizace“ československé společnosti. Ironická epoché zde otevírala pohled na ironii dějin, kde se jedněm zdálo být kýženou svobodou to, co jiní prožívali jako násilný útlak.

Na pozadí této biograficky podmíněné evidence se mi pomalu ujasňovalo, že Berger a Luckmann nemají na mysli pouze tu stránku sociálního konstruování, která tradičně spadá do oblasti sociologie vědění, ačkoliv by tomu podtitul knihy „A Treatise in the Sociology of Knowledge“ nasvědčoval. S Thomasem Luckmannem jsem se setkal poprvé až v roce 1974, kdy jsem na pozvání jeho asistentů začal učit na univerzitě v Kostnici, a netušil jsem ještě, že u obou autorů to bylo i jejich biografické pozadí, které jejich koncepci inspirovalo. Centrální otázka knihy, totiž jak se koncepty individuálního vědění mohou proměňovat $\mathrm{v}$ objektivní realitu, se netýká pouze procesu mediální objektivace subjektivního vědění a jeho proměny v kolektivní „stock of knowledge“, kterým jsou individua zpětně socializována. Sociální konstrukce reality v pojetí Bergera a Luckmanna není myšlena pouze jako teorie vzniku kolektivní zásoby vědění. Má více méně osvětlit proces, v němž je individuální myšlení a jednání transformováno v objektivní realitu, která, jak později Luckmann formuluje (Luckmann 1998: 22), komunikací a diskurzem osudově zasahuje do biografí́, identit a jednání individuí a skupin. Má se tak postihnout proces autogeneze, tedy sebeorganizace společností a zdůraznit jeho jak osudově objektivní tak i transitorní charakter.

Tento duální charakter toho, co sociální konstrukce reality vlastně znamená, je jedním z hlavních zdrojů shora zmíněné ambivalence textu, která se promítá i do jeho recepce. Teze, že realita je aktéry sociálně konstruována, sváděla $\mathrm{k}$ tomu, považovat sociální fenomény za „pouhéc konstrukce, které na základě své konstruovanosti nemohou pozvedat nárok na objektivitu, a zůstávají tak pouhým produktem jistých zájmových skupin, který je třeba dekonstruovat. Tato výtka se sice na jedné straně dala argumentačně použít ke kritice zdánlivé trvanlivosti stávajících struktur, na druhé straně vedla však k názoru, že Berger a Luckmann, jakož i celá fenomenologicky orientovaná sociologie, přehlížejí problém moci, panství a objektivních sociálních struktur (Habermas 1981). Tato kritika však přehlížela základní intenci, kterou Berger a Luckmann svým konceptem sledovali: totiž vysvětlit, jak „pouhé výmysly“ subjektivního vědomí nabývají objektivní moci, která, řečeno s Durkheimem, vystupuje vůči aktérům jako nutnost, nezávislá na jejich osobní vůli (Durkheim 1895). V tomto smyslu definuje později Luckmann (Schnettler 2006: 111) sociálně konstruovanou realitu jako takovou, 
která individuum časově předchází, je mu nadřazena a překračuje ho. Její základní charakteristikou je to, že není pouze realitou materiální, která je výsledkem jednání ve světě, ale i symbolickou, tj. realitou výkladu světa, jemuž je individuum též podř́zeno a jenž jej překračuje zrovna tak jako realita materiální. I tato symbolická skutečnost je výsledkem jednání, přesněji, jeho bipolárního charakteru. Jednání jako působení ve světě je vždy zároveň subjektivním prožíváním světa na straně jedné a praktickým konstruováním vztahů a objektů na straně druhé. Praxe jako proces této konstrukce je vždy i interakcí a komunikací. Jednání tak konstruuje realitu jako prožitek a jako materiální i semiotickou objektivní strukturu. Sociální svět je lidskou konstrukcí a člověk je zároveň konstruktem tohoto světa (Berger a Luckmann 1967: 61).

To, jak sociální konstrukty nabývají moci nad svými konstruktéry, Berger a Luckmann ukazují zpočátku na příkladě Gehlenova pojetí vzniku institucí (Gehlen 1972). Jedná se o v principu nenásilný proces rutinizace každodenních činností, kde jsou jisté problémy či situace opakovaně řešeny jednou již osvědčeným způsobem, takže vztah mezi aktérem, situací a řešením se pomalu mění. Bylo-li na počátku řešení daného problému závislé na aktérových vlastních rozhodnutích, je mu na konci procesu institucionalizace toto rozhodování odebráno, protože výskyt podobné situace v budoucnosti automaticky aktivuje rutinu, kterou se situace zvládá. Jednání v určitých situacích se tak stává kolektivně očekávatelným a očekávání rutinou definovaného „smysluplného“ jednání se proměňuje v sociální tlak, propůjčující vzorcům jednání objektivitu nezávislou na subjektivních intencích aktérů. Vnímání situací, jejich výklad a motivace adekvátního jednání se tak stávají sociálním konstruktem, jehož normativní potenciál se aktérům sděluje různými formami komunikace i korektivů, pakliže aktérovo jednání tomuto očekávání nedostačuje.

Tento v principu nevinný model toho, jak se individuální jednání komunikací proměňuje ve vzorce sociálně závazného výkladu situací a jejich zvládání, a tedy i ve vzorce formující zpětně subjektivní prožívání světa, není ve své platnosti omezen jen na rovinu každodenní interakce. Již ve své základní jednoduché podobě je tento model poznamenán ambivalencí: na jedné straně umožňuje pochopit, proč aktéři přebírají sociální konstrukty jako motivy své vlastní vůle. Na straně druhé však i ukazuje, že internalizací sociálních vzorců do subjektivního prožívání světa jsou tyto vzorce neustále ohrožovány tím, že se stávají předmětem vědomí subjektů a tudíž i jejich fantazie, která, jak Husserl i Schütz ukazují (Husserl 1999: $\S \S 41,74$; Schütz 2003: 211 a dále), je stálým pramenem jejich modifikace. Možnosti této modifikace se samozřejmě znásobují tím, čím je struktura společnosti komplexnější. Nutnost stabilizace a legitimace sociálních konstrukcí se tak se stupněm jejich komplexity neustále zvyšuje. Berger a Luckmann ukazují, že zdroje nadřazenosti sociálních konstruktů a moci jejich prosazování se mění se stoupající diferenciací společností, kde nejde jen o splňování každodenních očekávání, ale o podmínky platnosti symbolických univerz, v nichž společnosti žijí a která si navzájem konkurují o nárok na legitimní výklad světa. Centrální kapitolou knihy, kde se každodenní interakce propojuje s konstrukcí makrospolečenských struktur, je tudíž kapitola pojednávající o mechanismech fungování symbolických univerz smyslu.

Symbolická univerza jsou výklady světa osmyslující všechny segmenty společné reality a spojující každodenní praxi s oblastmi společnosti, které každodennost překračují. Na pozadí takových výkladů získává každodenní jednání svou legitimaci „vyšším“ smyslem 
a heterogenní očekávání společenských institucí, ukládaná každodenním aktérům, jsou zde spojována horizontem smyslu, mimo nějž světu není možno porozumět. Překročení této hranice znamená zhroucení dosud možného a vyvolává zlomy identit, traumata a společenské i životní krize. Symbolická univerza jsou semiotické dějinné produkty sociálního konstruování, tj. objektivizace a reprezentace subjektivních interpretací. Vznikají v procesech komunikace a jsou uchovávána mediálním tradováním. Jako produkty jednání umožňují tato univerza prožívání světa a tudíž i prožívání s tímto světem spojeného smyslu. Proto musí čelit riziku, které je dáno možností subjektivní modifikace smyslu zkušeností a prožitků a vstupem těchto modifikací do procesu komunikace. Symbolická univerza se snaží toto riziko eliminovat rozlišováním legitimního a nelegitimního vědění, definicí vzorců legitimních biografií a konečně i definicí smysluplných identit vybudovaných na přebírání každodenních praktik vedoucích $\mathrm{k}$ nabytí legitimního vědění a s ním spojených sociálních pozic. Symbolická univerza tak mají vždy co dělat s „temnou stránkou“ (Berger a Luckmann 1967: 96-97, 102-103) sociálního konstruování, která je $\mathrm{s}$ ním neoddělitelně spojena, totiž s možným chaosem alternativních konstrukcí a metamorfóz symbolického rádu, které číhají za jeho horizontem a mohou do něj kdykoliv proniknout. A paradoxně platí, že ačkoliv jsou tyto alternativní konstrukce symbolickým řádem vylučovány, právě tím do něj i vstupují. Toto riziko je signifikantně zvýšeno př́tomností alternativních symbolických univerz, at' už tato vznikají diferenciací vlastní společnosti, nebo setkáním s jinými kulturními okruhy. Riziko je zde dáno nejen tím, že už jen fakt existence alternativních možností výkladu světa ruší samozřejmost vlastního systému, ale i tím, že v pluralitě výkladů světa dochází ke konkurenci o definiční moc nad realitou, a tak i o ovládání procesu její konstrukce. I tento boj se opírá o model symbolické reprezentace očekávání a přejímání jejích výsledků každodenní praxí. Na obou těchto rovinách vznikají strategie, jejichž cílem je možné pronikání alternativních univerz smyslu do vlastního systému neutralizovat a zároveň zbavit alternativní konkurenty nároku na definiční moc.

Střet symbolických univerz a techniky jejich stabilizace mohl ostatně Luckmann pozorovat prímo na campusu frankfurtské univerzity pod okny své pracovny na Senckenbergově trrídě (Matthiesen 2006). Na jedné straně tohoto bulváru byla budova univerzity, v níž se nacházel jeho seminár. Naproti, na druhé straně třídy, stál a dosud stojí Institut für Sozialforschung, založený 1923, který se později ve 30. letech stal sídlem Frankfurtské školy. V 60. letech zde Horkheimer a Adorno rozvíjeli svou kritiku kapitalismu, která se stala nosnou ideologií studentské revolty. Luckmann, povolaný do Frankfurtu v roce 1965, tedy mohl se zájmem pozorovat základní praktiky mocenského boje mezi symbolickými univerzy nejrůznějších frakcí tohoto hnutí $\mathrm{i}$ to, jak se tyto boje promítaly do tragických konfliktů $\mathrm{v}$ biografiích jejich iniciátorů. Mezi pravou a levou stranou Senckenbergovy trrídy tak opravdu panoval rozdíl světů. Na jedné straně revoluční pokus zdiskreditovat symbolické univerzum občanské společnosti a nahradit ho utopickou vizí společnosti neznající odcizení a vykořistování. Na druhé straně, v poklidné atmosfére Luckmannova semináře, se tento pokus jevil jako typický př́pad sociálního konstruování jedné skutečnosti na základě destrukce skutečnosti druhé, kde proces komunikativní výstavby jednoho symbolického univerza pomocí dehonestace druhého hrál centrální roli. Strategie tohoto procesu, analyzované již v The Social Construction, zde mohly být sledovány in vivo, přičemž ironická distance této analýzy její břitkost ještě zintenzivnila. 
Základní techniky, kterými aktéři a instituce udržují platnost a legitimitu symbolických univerz, označují Berger a Luckmann jako terapii a nihilizaci. Terapie se obrací k těm „obyvatelům“ symbolického univeza, kteří již byli alternativními výklady světa ,infikováni“, a musí proto být uvedeni zpět na pravou cestu legitimní biografie. Tato technika vyžaduje jistou znalost alternativních univerz jak na straně ,,infikovaných“, tak na straně terapeutů. Ti poslední definují „katalogy“ příznaků, jimiž je možno odchylné mínění, chování a postoje identifikovat, a také techniky, kterými lze odpadlíky „očistit“ a převést zpět na pravou cestu. Definice odchylky v programech totalitárních stran a instituce sebekritiky jsou př́íkladem této praxe. Tato má samožrejmě mnoho variant v rámci náboženských, politických a jiných morálně-normativně definovaných systémů, kde instituce jako zpověd', sebekritika či manželské poradenství obnovují platnost legitimního smyslu světa pro individuální jednání a včleňují tak subjektivní prožívání a biografie zpět do horizontu kolektivního univerza smyslu. Zatímco se terapie snaží neutralizovat vlivy alternativních výkladů světa na úrovni individuálního chování, je účelem nihilizace podvrácení legitimity altenativních univerz smyslu tím, že jejich axiomy transformuje do vzorců myšlení a jednání vlastního univerza, čímž jejich podvratná síla mizí. Úspěšná nihilizace je tak zároveň důkazem nadřazenosti, a tudíž i pravdivosti vlastního symbolického univerza.

Obě tyto techniky nečerpají samozřejmě svou moc z pouhé existence toho kterého symbolického univerza smyslu, nýbrž vyžadují jednání aktérů, kteří jsou nositeli této sociální konstrukce. Ne všichni aktéři jsou ovšem automaticky povoláni k tomu, aby vstupovali do diskurzů, v nichž jde o legitimitu vědění a jednání a o prostředky její stabilizace. I když by se mohlo zdát, že symbolická univerza jsou pevně skloubenými systémy, uchovávanými tradicí, vidíme při bližším přihlédnutí, že tomu tak není. Kdo a z jakých důvodů se stává aktérem diskurzů a co je v nich výsledně legitimováno jako momentálně platný soubor vzorců myšlení a jednání, jimž je podřízena další komunikace, to vše je výsledkem interakcí, jejichž výstupy nejsou předem předvídatelné a jejichž suma vytváří to, čemu říkáme dějiny. Zde nacházíme zdroj ambivalence, vlastní sociální konstrukci skutečnosti, která na jedné straně vystupuje vůči svým aktérům jako nadřazená objektivita, vybavená mocí, formující jejich identity a jejich svět žití, na druhé straně je však realitou transitorickou, stále proměnlivou, která však přesto vnáší svou objektivitou do subjektivního prožívání aktérů zlomy a zvraty, jimž nemohou uniknout ani tehdy, když tento ambivalentní mechanismus sociálního konstruování nahlížejí.

Toto teoreticky jen komplikovaně postižitelné propojení mechanismu sociální konstrukce s jeho bezprostředním dopadem na každodennost aktérů se Berger a Luckmann snaží čtenáři přiblížit již zmíněným prostředkem ironické distance, s níž volí své ilustrativní příklady z každodenního života. Rozkrývají tak každodenní samozřejmost situací a ukazují jejich komplexně konstruované pozadí. Tato často vtipná lehkost textu vytváří dojem jisté vídeňské lehkovážnosti, kterou musí čtenář nejprve proniknout, aby se probral k podstatným teoretickým výpovědím. Ironická distance zde přitom není jen pouhou literární formou. Autoři se její pomocí snaží dosáhnout sociologického postoje, který je vynucován samotným principem sociálního konstruování, v němž je člověk aktérem a pozorovatelem zároveň. Platí-li toto pro aktéry každodenní, pak to platí pro situaci sociologa o to více. Berger a Luckmann si jsou samozřejmě vědomi, že výsledkem jejich jednání jako autorů je prŕíspěvek k sociální konstrukci reality. Jednou z možností, jak k tomu kognitivně i literárně zaujmout reflektovaný 
postoj, je prostředek ironické distance $\mathrm{k}$ přednášenému. Autoři tak signalizují, že za svou tezí stojí, ale že jsou si zároveň vědomi toho, že platnost jimi zastupované teze předpokládá, že je ji možno přednést - konstruovat - i jinak.

Být zároveň pozorovatelem i částí pozorovaného předmětu je samozřejmě typická pozice sociologie jako sebepopisu společnosti. Tento fakt může být kognitivně akceptován jako výsledek teoretické úvahy, ale pro jeho kognitivní zvládání a převedení do vědecké praxe je zapotřebí jisté vnímavosti a životní zkušenosti, která není samožrejmou výbavou každého sociologa. A není zřejmě náhodou, že to byli Berger a Luckmann, jimž představa sociálního konstruování jako propojení subjektivního proživání a objektivity sociálních struktur, které ve své proměnlivosti osudově zasahují do biografií aktérů, připadala jako popis fungování společnosti pravděpodobná, ne-li prímo samozřejmá. Zde hraje roli jejich biografické zakotvení ve středoevropském prostoru a jeho bouřlivých společenských proměnách během minulého století, zejména pak ve Vídni a v atmosfére mnohonárodní, polyethnické rakousko-uherské monarchie. Nejde zde ani tak o jakousi identifikaci s politickou skutečností rakousko-uherského mocnářství. Spíše je jejich intelektuální výbava poznamenána senzitivitou pro pluralitu symbolických univerz zastoupených $\mathrm{v}$ tomto útvaru a pro vratkost diskurzů, ve kterých se po staletí jednalo o vytvoření a udržení jejich jednotného rámce a které přesto vedly $\mathrm{k}$ rozkladu tohoto mocnářství $\mathrm{v}$ důsledku totalizující symbolické moci nacionalistických výkladů světa. Zkušenost rozpadu zdánlivě neporušitelné říše pod vlivem nacionalistického diskurzu a jeho kruté praxe $\mathrm{v}$ podobě první světové války vytvářela atmosféru po roce 1918, kterou byli Berger a Luckmann ve svém mládí obklopeni, jak jejich biografická svědectví ukazují (Berger 2016; Dreher a Göttlich 2016; Steets 2016; Schnettler 2006). Dalo by se říci, že pro ně byla zažitou evidencí osudové moci sociálního konstruování.

Tuto atmosféru líći řada literárních svědectví jako Vančurův Konec starých časů nebo Zweigův Svět včerejška (Die Welt von Gestern) a obzvláště Musilův Muž bez vlastností (Der Mann ohne Eigenschaften). Je to právě Musilův román, který svým pojmem „Kakánie“, odvozeným ze zkratky „K.u.K. Monarchie“ (císařsko-královské mocnářství), a rozborem jeho vlastností tuto atmosféru obzvláště plasticky zachytil. Povědomí ztráty jistot a konfrontaci Kakánie s modernou vyvolává Musil kupříkladu v následující pasáži:

Ta věc (tj. moderna - pozn. I. Š.) nás má v hrsti. Dnem i nocí s ní uháníme a děláme během toho všechno možné: holíme se, jíme, milujeme, čteme knihy, vykonáváme své povolání, jakoby ty čtyřri stěny, jimiž nás obklopuje, stály pevně a v klidu. Zrada spočívá v tom, že ty čtyři stěny se také někam řítí, aniž bychom to pozorovali, razí si cesty jako klikatá tykadla šíŕící se všemi směry, aniž bychom my věděli kam... A nás se zmocňuje čím dál naléhavěji pocit, že jedeme špatným směrem, že jsme přestřelili daleko přes původní cíl. Chtěli bychom vystoupit, seskočit, vrátit se k bodu, který ležel před tím, než se špatně odbočilo... Za oněch časů, kdy rakouské císařství ještě existovalo, bylo $\mathrm{v}$ takovém případě možné $\mathrm{z}$ toho šíleného vlaku času ještě vystoupit a přesednout na normální dráhu, vedoucí domů. (Musil 1987: 32, překlad I. Š.)

Berger $(1983,1988)$ ve svých vzpomínkách a textech zaznamenává, jak důležitý tento román pro něj byl a je, srovnatelně s významem Haškova Švejka pro leckterého českého intelektuála. I pro Luckmannovo myšlení hraje tato atmosféra svou roli, jak dále uvidíme. Musilova Kakánie byla jakousi empirickou evidencí symbolického metauniverza, které svým 
rámcem zahrnovalo a osmyslovalo pluralitu kulturních, náboženských a etnických subuniverz. Tu vyjadřovalo již oficiální motto tohoto státního útvaru - „Ex pluribus unum“. Musil z této evidence vyvozuje pohled na svět, který je základní charakteristikou jeho románu. Zdánlivá jednota a danost věcí tohoto světa se při bližším přihlédnutí jeví jako konfigurace možných perspektiv, které se v průběhu času mění. Ani skutečnost, ani aktéři tak nemají pevné vlastnosti. Jejich zdánlivé vlastnosti jsou pouze transitorními možnostmi, jejichž udržování vyžaduje námahu a činnost. Proto dochází Musilův hrdina $\mathrm{k}$ závěru, že nejpohodlnější variantou je se vlastností zcela vzdát. Tím by byla, teoreticky vzato, dosažena i ideální pozice objektivního pozorovatele, jemuž by se tak nabízel pohled na mechaniku konstrukce zdánlivě nekonstruovaného světa.

Právě tuto vnímavost pro sociální konstruovanost a ambivalentní charakter skutečnosti, podmíněnou zkušeností rozkladu Rakouska a jeho symbolického univerza pod tlakem alternativních sociálních konstrukcí, nacházíme i u našich autorů. Luckmann, narozený v roce 1927, se ve svých vzpomínkách (Schnettler 2006: 17 a dále) sám vidí jako př́slušník „mezigenerace“, která již nepatřila k Rakousku-Uhersku, ale byla jím přesto ještě ovlivňována, takže nepatřila zcela $\mathrm{k}$ Rakousku pohabsburskému. Násilnost mocenských nacionalistických a třídních diskurzů, jimiž byla společenská skutečnost té doby redefinována, nebyla tak pro Luckmanna jen akademicky registrovaným historickým faktem, ale pronikala do jeho biografie: jeho otec byl roku 1942 zastřelen komunistickými partyzány a on sám byl v posledních týdnech druhé světové války jako sedmnáctiletý zraněn a zajat, než se mu po dobrodružném útěku podařilo stát se opět žákem gymnázia a získat maturitu, která mu umožnila pokračovat později ve studiu jak v Rakousku, tak na New Yorské New School for Social Research. Zde se setkal s těmi představiteli rakouského a německého intelektuálního života, které německý národní socialismus přinutil opustit Evropu a hledat útočiště na „University in Exile“, která byla prestižní součástí New School. Setkal se zde s Peterem Bergerem a se svými učiteli Albertem Salomonem, Karlem Mayerem a Karlem Löwithem. Především však zde bylo rozhodující setkání s Alfredem Schützem, jehož nedokončené dílo o struktuře přirozeného světa žití Luckmann později na základě Schützovy pozůstalosti zpracoval a dovedl do konce (Schütz a Luckmann 2003).

Sociologický výzkum Luckmanna zavedl do poválečného Německa $\mathrm{v}$ rámci projektu zabývajícího se otázkou, zdali působení církví a náboženské cítění německého obyvatelstva může přispět jeho k demokratické převýchově (Schnettler 2006: 27). Na tematickém horizontu se tak pomalu vynořují otázky, které ho budou zaměstnávat během celého akademického života: první dvě pramení ze sociologické tradice, která na ně nepodává uspokojivé odpovědi. Je to zaprvé problém vlivu symbolických univerz na každodenní způsob života, v němž již Max Weber viděl původ odlišného vývoje kultur a společností orientu a okcidentu. Zadruhé je to otázka Durkheimova, odkud se bere schopnost sociálních fenoménů vykonávat tlaky orientující individuální jednání. Fakt, že mechanismus normy a sankce zde zdaleka nepodává vyčerpávající vysvětlení, vyžadoval další zkoumání. Odtud vede cesta k základním tezím Social Construction, kde je tento problém řešen jako objektivizace a internalizace orientací jednání $\mathrm{v}$ procesech interakce a především komunikace. Je to pak hlavně proces komunikace, který se pro Luckmanna stále více stává tím, co „drži““ společnost pohromadě. Již ve svém zkoumání moderní religiozity dochází $\mathrm{k}$ závěru, že vliv náboženského prožitku 
na jednání individuí není dán pouze působením tradičních náboženských systémů vědění. Proti tomu mluví fakt, že jejich univerzální vliv v modernitě klesá, zatímco náboženské cítění a prožívání zůstává. $Z$ tohoto pozorování plyne Luckmannův koncept „neviditelného náboženstvi'“ (Luckmann 1967). Náboženské prožívání je zde pojímáno jako prožívání transcendence, tj. překračování člověka skutečností, ale i sebou samým. Prostředkem takového překračování transcendence, a tedy i cizosti mezi individui, je komunikace, která zde není jen přenášením informací, nýbrž procesem, v němž vznikají vzorce jednání a myšlení, a tudíž i kritéria jeho správnosti, tj. morálka (Luckmann 1998: 27 a dále).

Ve výzkumu morální komunikace se Luckmannovi otevírá empirický př́stup k procesům sociálního konstruování, jehož osudový vliv na prožívání světa již teoreticky analyzoval s Bergerem. Moralizace skutečnosti se již zde ukázala jako mocenský prostředek legitimace výkladu světa jakož i praxe, která tento výklad prosazuje. Již v Social Construction je řeč a jazyková komunikace základní nositelkou legitimace symbolického univerza smyslu, a tudíž i kritérií správnosti jednání a myšlení (Berger a Luckmann 1967: 92-93). Jako není úniku před komunikací, není ani úniku před internalizací morálních pravidel. Zároveň je však tezí sociálního konstruování, že jeho výsledkem je pluralita výkladů světa, a tudíž i možných morálek. Zde můžeme mít opět důvodně za to, že tento závěr sociologického rozboru není jen teoretickým náhledem, ale i výsledkem životní zkušenosti získané v prostředí Kakánie. Obyvatelé této země, píše Musil,

jednali vždy jinak, než mysleli a mysleli jinak, než jednali... Každý z nich měl alespoň devět charakterư: jeden profesní, jeden národní, jeden státoobčanský, jeden tř́́dní, jeden regionální, jeden genderový, jeden vědomý a jeden nevědomý, a nejspíš k tomu ještě i jeden privátní. Spojoval je $\mathrm{v}$ sobě a ony ho v sobě jaksi rozpoušťlly, takže člověk nebyl ničím jiným než jakousi vymletou úžlabinou, do níž všechny tyto stružky prosakovaly a z níž mohly zase přetékat jinam, aby se spojovaly v něco nového. Proto měl každý obyvatel této země ještě jeden, desátý charakter, existující jen $\mathrm{v}$ jeho fantazii jako nevyplněný prostor a sloužící $\mathrm{k}$ tomu, aby nemusel brát vážně nic $\mathrm{z}$ toho, jak se jeho devět ostatních charakterů chová a k čemu ho nutí. (Musil 1987: 34, překlad I. Š.)

Zde jsou ironická distance a smysl pro proměnlivou pluralitu morálky zabudovány takříkajíc do rakouského národního charakteru. Není tedy divu, že Luckmannovi zůstalo blízké myšlení dvou jiných velkých Rakušanů - totiž Edmunda Husserla a Alfreda Schütze a jejich fenomenologie. Základním metodologickým postojem fenomenologického myšlení je pokus vystoupit pomocí fenomenologické redukce z danosti světa a získat tak pozici, z níž je možno přihližet tomu, $v$ jakých aktech vědomí a jednání tato danost vzniká. Dalo by se tedy ř́íci, že se zde ironická distance spojuje s rigorózností fenomenologické analýzy, čímž se Musilem zachycený životní postoj proměňuje $\mathrm{v}$ metodologické pravidlo. Jistým způsobem se zde realizuje i Schutzův metodologický postulát adekvátnosti vyžadující, aby teoretické konstrukce měly vždy svůj základ v postojích přirozeného světa (Schütz 2010: 375). Co se pak výzkumu morálky týče, plyne z toho pro Luckmanna, že je sice možno ukázat, že je morálka pro sociální konstrukci skutečnosti nevyhnutelná, že je možno odhalit způsob jejího vznikání a mechanizmy její platnosti, ale že není možno ani vědecky, ani filozoficky rozhodnout, která z jejích empiricky existujících variant by měla platit více než jiná. Ironická distance jako metodologický postoj zde vyžaduje nepřebírat žádnou z vlastností, které jsou pozorovateli 
tou či onou morálkou přisuzovány, a zůstat tak v ideální pozici člověka bez vlastností, což samozřejmě vyžaduje značnou dávku sebeironie.

Empiricky je možno se dobrat toho, jak morálka udržuje svou platnost, jen rozborem komunikace, v níž vzniká. Proto se Luckmann ve svém pozdějším díle zabýval druhy morální komunikace, tj. ustálenými sociálními žánry každodenní komunikace, v nichž je správnost jednání a myšlení definována a potvrzována, jako kupř. vyprávění, poučení, klepy atd. Tímto zaměřením na každodenní praktiky morální komunikace se Luckmann snažil dosáhnout empirické evidence o fungování „morální“ konstrukce skutečnosti. Oponoval tak normativním představám, které získávají kritéria rozhodování o dobrém či špatném způsobu morální komunikace $\mathrm{z}$ toho či onoho předem teoreticky definovaného symbolického univerza smyslu, jak to nacházíme třeba v Habermasově (1981) teorii komunikativního jednání. Takto viděno se klonil spíše k Luhmannovu názoru (1997: 245 a dále), že etické koncepce a etika všeobecně nejsou tím př́stupem k fenoménu morálky, který by byl schopen jeho fungování objasnit. Z toho pramenila i jeho skepse k diskuzím o morálce s teology a etickými filozofy, které ze značné míry právem podezíral, že jim je metodologická ironická distance cizí, a že fakt, že každý člověk - a tedy i oni - je i morálním subjektem, zaměňují s domněním, že tato jejich principiální moralita apriori znamená, že již vědí, která morálka je dobrá. Kdybychom měli formulovat jeho výslednou pozici v tomto ohledu, mohli bychom nejspíš rríci, že sice nelze vědecky, ani filosoficky rozhodnout, jaká morálka je dobrá, ale že je nemožné žádnou nemít. To by vysvětlovalo, proč mohl být navzdory (či právě kvůli?) ironické distanci k teologům hluboce věřícím člověkem.

Ironická distance nebyla Luckmannovi pouze metodologickou pozicí. Patřila $\mathrm{k}$ jeho osobnosti a charakterizovala jeho vztah k většině rolí, institucí a současníků, kteří ho obklopovali, i když ne vždy ve stejné míře. S ironií a humorem sledoval své kolegy shromažd'ující akademické úřady a funkce. Slavnostní projevy, rétorickou pompéznost i akademické mlácení prázdné slámy špatně snášel, což vedlo často k tomu, že podobné akce předčasně opouštěl. Neoslňovala ho řada publikací a četnost jejich sledovanosti, pakliže nedospěl sám k závěru, že jejich obsah je podstatným př́nosem $\mathrm{k}$ pojednávanému problému a nikoliv jeho pouhou reprodukcí či modifikací v rámci právě trendové terminologie. Zde se jeho ironická distance proměňovala v ostrý analytický nástroj, jímž bez ohledu na osobu a pozici analyzoval předkládané teze a konfrontoval jejich substanci s dostupnou empirickou evidencí. Kdo v takové zkoušce neobstál, vưči tomu zachovával svou „starorakouskou“ zdvořilost, ale jako seriózní spoludiskutant v akademickém diskurzu byl pro něj až na další ztracen a bylo velmi obtížné takto ztracenou pozici opět vydobýt. Nárok na uznání v akademické obci tak pro Luckmanna plynul jen z vědeckého př́nosu a nikoliv z formálních funkcí a hierarchických pozic. Tato vědecká přísnost vůči jiným byla založena na vysokém nároku, který měl na svou vlastní práci. Použití toho či onoho pojmu v teoretické diskuzi nebo při vyhodnocování empirických dat se nikdy nedělo pouze „kolokviálně“،, ale stálo za ním vždy systematické zdůvodnění. Proto trval vždy na tom, že fenomenologický a antropologický rámec sociologického zkoumání musí být vždy považován za protosociologickou koncepci, jejíž teze a metody nelze bez dalšího používat jako prostředky empirického sociologického šetření. Do oblasti protosociologie patřila především fenomenologická analýza konstituce smyslu v aktech vědomí, kterou přísně odděloval od empiricky přístupné sociální konstrukce skutečnosti v procesech 
interakce a komunikace. Směšování obou pojmů v textu třeba jen ze stylistických důvodů vynášelo autorům vždy káravý komentár. Ačkoliv se sám nikdy nestylizoval do role univerzitního pedagoga, vedla jeho vědecká reputace a osobnost $\mathrm{k}$ tomu, že se stal centrální postavou teoretického směru fenomenologicky orientované sociologie založené na kvalitativních metodách výzkumu. V tomto smyslu vychoval několik generací sociologů, kteří podstatně ovlivnili a ovlivňují vývoj německé i světové sociologie. Vliv jeho prací nebyl omezen pouze na obor sociologie. Byl vyhledávaným členem mnoha interdisciplinárních výzkumných skupin i projektů a koncept sociálního konstruování se stal inspirací nových cest v řadě humanitních oborů.

Luckmannova osobnost však není vystižena jen akademickými výkony. K jeho životu patřila řada rolí a činností zcela neakademického rázu. Náruživě provozoval rybaření na mušku a vyhledával patřičná loviště na všech kontinentech. Své úlovky nikdy nepojídal, ale v rámci sportovního fair play vždy vracel do jejich elementu. Nekrvavým lovcem byl i jako ornitolog. Alpské lyžařské túry a sjezdy patřily k tradičním akcím kostnických sociologů a obávaný byl zvláště jako hráč bridge $\mathrm{s}$ přísnými nároky na své spoluhráče. Svou roli řádného profesora tak vyplňoval více než neortodoxně a právě to z něj činilo výjimečnou osobnost, která svou pouhou existencí byla motivací druhým. Peter Berger jako blízký př́itel $\mathrm{k}$ těmto facetám Luckmannovy osobnosti přidává ještě jednu, která možná odpovídá Musilově desátému charakteru. Žertem vyslovuje podezření, že si v hloubi duše Luckmann pohrával s představou, jak projíždí coby důstojník císařské gardy ve slavnostním průvodu ulicemi Vídně. Bylo-li tomu tak, pak nám Luckmannova diagnóza globalizované společnosti na konci 20. století ukazuje, že tato šance je navždy ztracena.

Luckmann píše: „Dnes víme, že existuje jen jeden svět, víme ale také, že tento není totožný s naší vlastní kulturou, nýbrž že sestává z nepřehledné změti různých kultur a společenských struktur. Přesto pocit'uje každý člověk na vlastní kůži, že nadregionální a globální poměry politických a ekonomických procesů přes velké vzdálenosti jeho život podstatně a dlouhodobě ovlivňují, a ví také, že tyto síly jsou vystaveny rychlým změnám a mohou jeho život změnit i ohrozit. Zrovna tak ví, že politická, ekonomicky-racionální a byrokratická rozhodnutí učiněná někde $\mathrm{v}$ nepřehlednu komplexních společností spolurozhodují o jeho osudu, aniž by se proti nim mohl někam či k někomu odvolat“" (Luckmann 1998: 22). Dalo-li se podle Musila z šíleného vlaku moderny v Kakánii ještě vystoupit, ukazuje nám Luckmannova velmi podobná diagnóza globální postmoderny, že to dnes již určitě nelze. A přeci: s Luckmannem a jeho ironickou distancí, která byla schopna rozebrat pocitovanou absurditu tohoto světa, zviditelnit ji a tím ji alespoň na chvíli na lidsky snesitelnou míru zredukovat, to bylo alespoň v krátkých okamžicích rozhovorů možné. Thomas Luckmann zemřel 10. května 2016 v Korutanech, ve věku 88 let.

\section{Literatura}

BERGER, Peter L. 1983. „Das Problem mannigfaltiger Wirklichkeiten: Alfred Schütz und Robert Musil.“ Pp. 229-251 in Richard GRATHOFF a Bernhard WALDENFELS (eds.). Sozialität und Intersubjektivität. München: Fink Verlag. 
BERGER, Peter L. 1988. „Robert Musil und die Errettung des Ich.“ Zeitschrift für Soziologie 17(2): $132-142$.

BERGER, Peter L. 2016. „Interview.“ Soziologie 45(3): 271-278.

BERGER, Peter L. a Thomas LUCKMANN. 1967. The Social Construction of Reality. New York: Doubleday.

DREHER, Jochen a Andreas GÖTTLICH. 2016. „Structures of a Life-Work: A Reconstruction of the Oeuvre of Thomas Luckmann." Human Studies 36(1): 27-50.

DURKHEIM, Émile. 1895. Les règles de la méthode sociologique. Paris: Félix Alcan.

GEHLEN, Arnold. 1972. Der Mensch: seine Natur und seine Stellung in der Welt. Wiesbaden: Athenaion.

HABERMAS, Jürgen. 1981. Theorie des kommunikativen Handelns, Bd. 1. Frankfurt am Main: Suhrkamp.

HUSSERL, Edmund. 1999. Erfahrung und Urteil. Hamburg: Meiner.

LUCKMANN, Thomas. 1967. The Invisible Religion. New York: MacMillan.

LUCKMANN, Thomas (ed.) 1998. Moral im Alltag. Gütersloh: Verlag Bertelsmann Stiftung.

LUHMANN, Niklas. 1997. Gesellschaft der Gesellschaft, Bd. 1. Frankfurt am Main: Suhrkamp.

MATTHIESEN, Ulf. 2006. „Das Wissen des Karneades in der Hauptstadt der Kritischen Theorie. Thomas Luckmann in Frankfurt am Main 1965-1970.“ Pp. 337-344 in Dirk TÄNZLER a Hubert KNOBLAUCH (eds.). Neue Perspektiven der Wissenssoziologie. Konstanz: UVK.

MUSIL, Robert. 1987. Der Mann ohne Eigenschaften. Rheinbeck: Rowolth.

SCHNETTLER, Bernd. 2006. Thomas Luckmann. Konstanz: UVK.

SCHÜTZ, Alfred. 2003. „Über die mannigfaltigen Wirklichkeiten.“ Pp. 177-248 in Martin ENDRESS a Ilja SRUBAR (eds.) Theorie der Lebenswelt 1 - Die pragmatische Schichtung der Lebenswelt. Konstanz: UVK.

SCHÜTZ, Alfred. 2010. „Wissenschaftliche Interpretation und Alltagsverständnis menschlichen Handelns.“ Pp. 329-400 in Thomas S. EBERLE, Jochen DREHER a Gerd SEBALD (eds). Alfred Schütz Werkausgabe Band IV: Zur Methodologie der Sozialwissenschaften. Konstanz: UVK.

SCHÜTZ, Alfred a Thomas LUCKMANN. 2003. Strukturen der Lebenswelt. Konstanz: UVK.

STEETS, Silke. 2016. „What Makes People Tick? And What Makes a Society Tick? And is a Theory Useful for Understanding?: An Interview with Peter L. Berger.“ Human Studies 36(1): 7-26.

\section{Autor}

Ilja Šrubar̆ podle svých vlastních slov „vždy visel mezi sociologií a filosofií“. Univerzitní studium zahájil v Praze, ale roku 1969 odešel z Československa do Německa. V letech 1974-92 působil na Kostnické univerzitě, v roce 1992 na Humboldtově univerzitě v Berlíně a od roku 1993 na univerzitě v Erlangen; v roce 1987 se stal docentem, 1992 profesorem sociologie. Dlouhodobě se věnuje fenomenologické sociologii (zejména dílu Alfreda Schütze), ale též dějinám sociologie, sociologii kultury nebo sociologii řeči. Mezi jeho důležité knižní publikace patří např́iklad práce Alfred Schütz: Theorie der Lebensformen (1981) nebo Kultur und Semantik (2009).

Kontakt: ilja.srubar@soziol.phil.uni-erlangen.de 